Victoria Jackson

York University

\title{
Aitana Guia, The Muslim Struggle for Civil Rights in Spain: Promoting Democracy Through Migrant Engagement, 1985-2010 (Brighton: Sussex Academic Press, 2014). 224 pp. \$34.95 Paperback.
}

\begin{abstract}
Aitana Guia's The Muslim Struggle for Civil Rights in Spain: Promoting Democracy Through Migrant Engagement, 1985-2010 is an important investigation of organised Muslim groups and their campaigns for status and rights in Spain since 1985. Skilfully engaging with multiple historiographies, Guia roots her study in the growing body of literature on the "bottom-up" history of Spain's celebrated transition from dictatorship to democracy. Like historians Pamela Radcliff and
\end{abstract} Antonio Cazorla-Sánchez, who locate the popular origins of the transition in the emergent civil society of the 1960s, Guia employs a thick conception of citizenship and adopts Geoff Eley's notion that democratisation is the product of popular pressure. However, in contrast to these other Spanish historians, Guia does not mark the culmination of democratic mobilisations by the 1978 Constitution. Rather, she argues that the subsequent struggles of immigrants and religious minorities renewed public debate over citizenship and contributed to the deepening of democracy, overturning the notion that Muslims are "incapable of embracing democratic politics since Europe's tradition of secularism clashes at the most fundamental level with the trenchant religiosity of Muslim migrants" (8).

Guia begins her investigation with the first Immigration Act of 1985, which limited the opportunities for Muslims to legalize their permanent status in Spain. Although the Act purported to recognize Spain's colonial past, it only facilitated naturalization for the descendants of expelled Sephardi Jews and former colonial subjects from Latin America, Portugal, the Philippines, Andorra, Equatorial Guinea and Gibraltar who "identified with or had a cultural affinity to Spain" (14). The descendants of expelled Muslims and Moriscos, former colonial subjects from Morocco and Western Sahara, and the long-time Muslim residents of Spain's disputed enclave cities in North Africa were not designated as cultural affinity groups. In the divided enclave city of Melilla, the Act exacerbated longstanding tensions as the city's nativist colonial settlers attempted to undermine Muslim residents who organised to "protest a law that wants to inflict damage on a community which, for its nature and rootedness [arraigo], can never be considered foreign" (Organizing Committee of the Muslim People, 30). Following a three-year campaign, which precipitated nativist reprisals and the disaffection of some Muslim leaders who began to advocate Melilla's return to Morocco, the Spanish government granted citizenship to Muslims with ten or more years of residency in the enclaves and clarified that the Immigration Act would only apply to foreigners who could not prove their arraigo. In addition to achieving citizen- 
ship for thousands of Muslim residents, the struggle in Melilla reinforced civil society and undermined nativist tutelage in the city. It also established an important precedent for migrant activism and immigration reform throughout Spain. During the 1990s and 2000s, migrant groups all over the peninsula established independent organisations with solidarity ties to NGOs and trade unions as they successfully mobilized for regularization by arraigo as an ordinary path to achieving permanent status in Spain.

The second part of Guia's study, which deals with religious and cultural rights, begins in 1992, when the Spanish government signed the Agreement of Cooperation with the Islamic Commission of Spain. Similar to earlier agreements with the Catholic Church, the Agreement of Cooperation conferred a variety of privileges and legal protections to practicing Muslims, acknowledging that Islam played an "important role in the formation of Spanish identity" and reiterating that Islam was 'deeply rooted' [notorio arraigo] in the country" (83). However, as Spanish authorities have been reluctant to implement the Agreement, it has catalysed Muslim groups to continue mobilising for religious and cultural pluralism while reclaiming "Spain's Islamic past as an instrument of social inclusion and political legitimacy" (130). To date, these mobilisations have mainly fuelled hostilities, particularly in the autonomous region of Catalonia, where Muslim activism has been interpreted as a challenge to the Catalan nationalist project. Guia, however, remains hopeful that the ongoing efforts of Muslims in Spain will ultimately contribute to the deepening of democracy by securing equal treatment for all religions and initiating "fruitful multicultural dialogue" (160).

As much of the scholarship on Western Muslims has been concerned with whether Muslims pose a threat to Western societies or add to the religious, cultural, and political diversity of Western nation-states, Guia's contribution lies less in the novelty of her argument and more in her detailed account of Muslim organisations and their methods of political engagement. In this regard, Guia should be especially commended for her sensitivity to the position of women, the divisions within and between Muslim groups, and the affects of domestic tensions and geostrategic concerns on the "spectrum of possibilities" for Muslims in Spain (117). What is more, by successfully integrating the struggles of Muslim migrants into the narrative of democratisation Guia's study also contributes to the field of modern Spanish history, promising to initiate new discussions regarding the relationship between the postcolonial logic of democratic officials and the development of attitudes towards Muslims and the Islamic past in Spain.

Andrea Davis

University of California, San Diego 